\title{
Laugier-Hunziker syndrome: a rare disease entity
}

\author{
Zespół Laugiera-Hunzikera - rzadka jednostka chorobowa
}

Przegl Dermatol 2016, 103, 417-419 DOI: 10.5 | |4/dr.2016.62895

Dear Editors,

Laugier-Hunziker syndrome (LHS) is a rare, acquired, idiopathic disease of benign nature characterized by pigmentation of the oral mucosa, lips and longitudinal melanonychia [1]. Around 100 cases of the disease have been reported, mostly from Europe. We report a case of LHS from India with additional penile pigmentation, making our case a unique presentation.

A 20-year-old man presented with progressive darkening of the tongue, nails, palms, soles and genitals for the last 4 months. The patient gave no history of any long-term medications, smoking, radiation exposure, precocious puberty, dark colored stools, abdominal pain, breathlessness or weakness. There was no history of any gastrointestinal or mucosal pigmentary disease in other family members. Examination revealed well-defined, coalescent hyperpigmented macules on the palms, soles and dorsal aspects of the

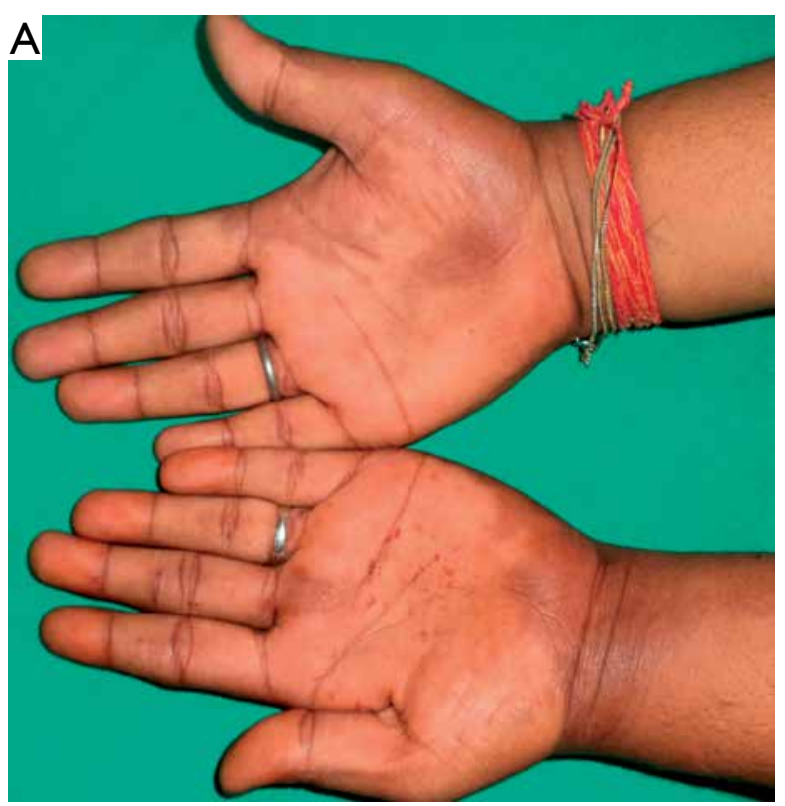

hands but sparing the palmar creases (Figures $1 \mathrm{~A}-\mathrm{C}$ ). Macular, slate gray pigmentation was present over the dorsal surface of the tongue (Figure $2 \mathrm{~A}$ ). The rest of the oral mucosa was not involved. The glans penis showed multiple, slate gray to violaceous, hyperpigmented macules in a reticulate pattern (Figure $2 \mathrm{~B}$ ). There were also some depigmented macules over the glans which the patient ascribed to some painful vesicular eruption, possibly herpes genitalis in the past (Figure $2 \mathrm{~B}$ ). The fingernails showed several longitudinal streaks of melanonychia with involvement of the proximal nail folds - a positive pseudo-Hutchinson sign (Figure $1 \mathrm{~B}$ ). Toe nails were spared. Histopathology from a hyperpigmented macule from the palm showed hyperkeratosis, acanthosis and increased basal layer pigmentation. Systemic examination was unremarkable. Routine laboratory investigations including blood count and liver and renal function tests were normal. The adrenocorticotropic hormone
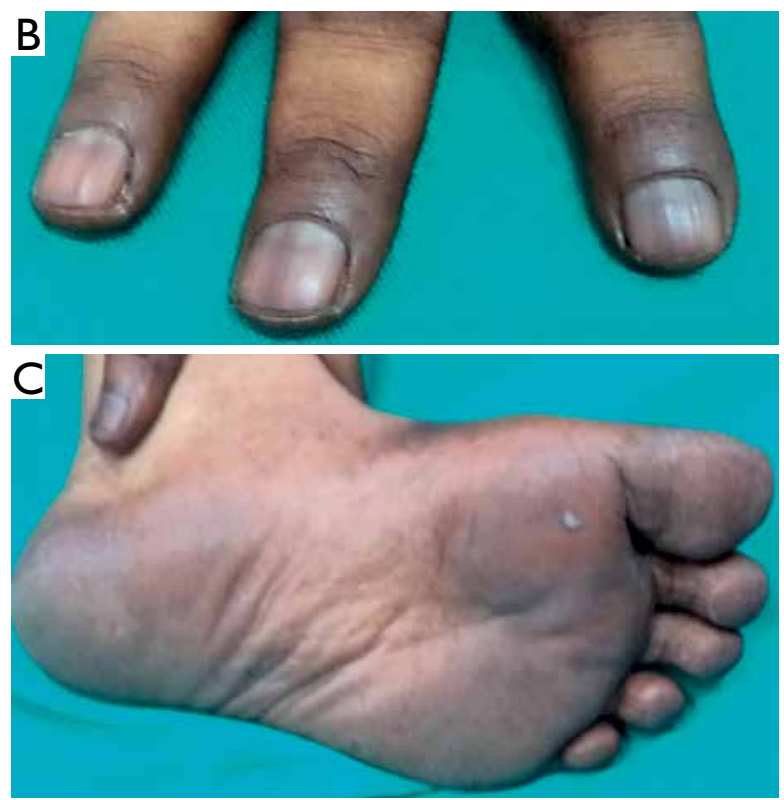

Figure I. A - Well-defined macular hyperpigmentation over the palms; B - longitudinal melanonychia with pigmentation of proximal nail folds and the adjacent skin of the digits; $C$ - Slate gray macular pigmentation over soles

Rycina I. A - Dobrze odgraniczone przebarwienia na dłoniach, B - podłużne przebarwienia paznokci z zajęciem bliższego wału i otaczajqcej skóry palców, $\boldsymbol{C}$ - ciemnopopielate plamiste przebarwienia na podeszwach 

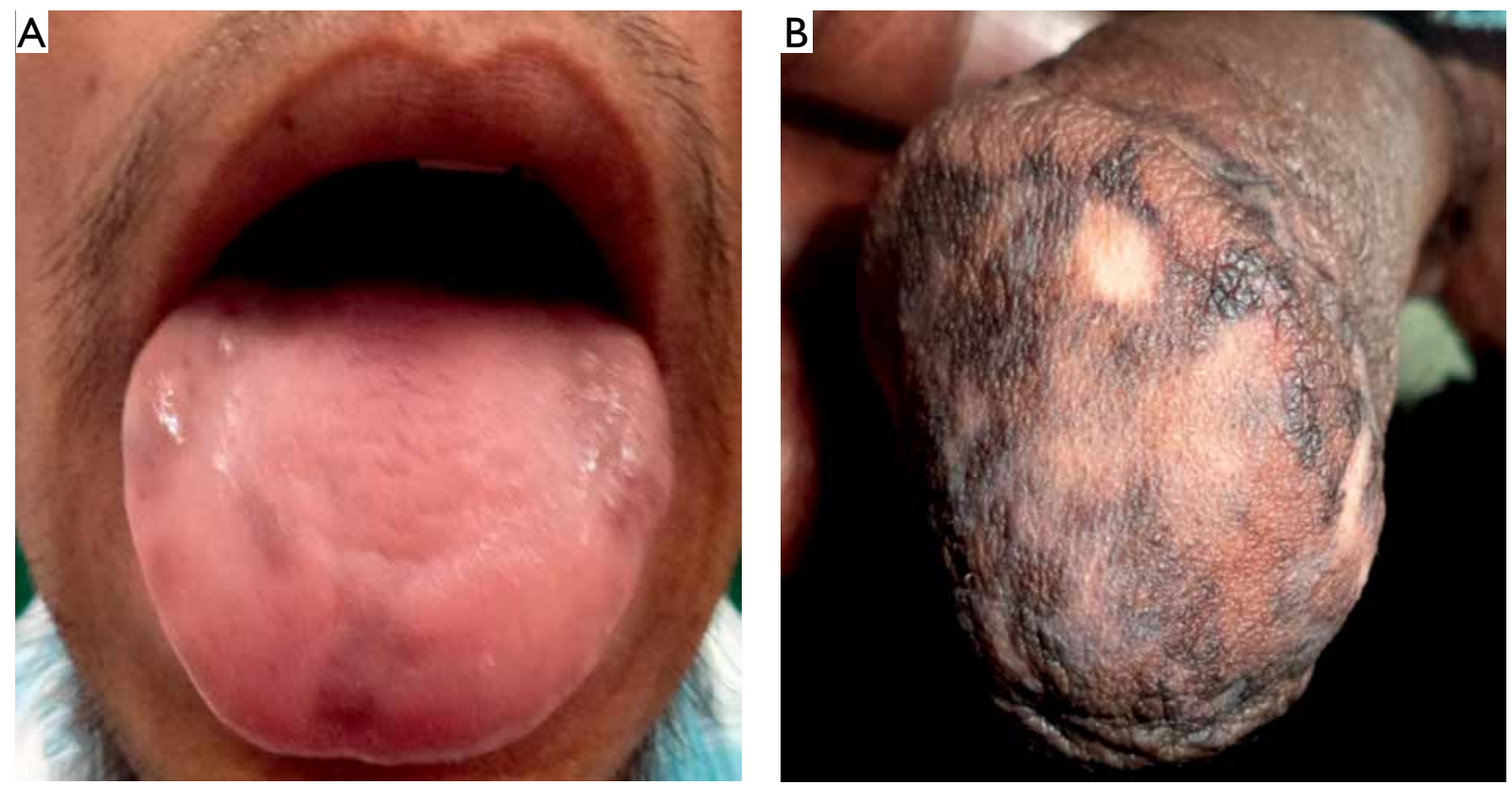

Figure 2. A - Patches of slate gray pigmentation over the dorsal surface of the tongue, B - Slate gray to violaceous pigmentation of the glans penis in a reticulate pattern. Note the post-inflammatory depigmented macules secondary to herpes genitalis

Rycina 2. A - Ogniskowe, ciemnopopielate przebarwienie na grzbietowej powierzchni języka; B - ciemnopopielate i sinawe siateczkowate przebarwienie na żołędzi. Obecne również plamiste odbarwienia pozapalne (po opryszczce)

(ACTH) levels, serum cortisol and serum vitamin $\mathrm{B}_{12}$ levels were within the normal range. No abnormality was detected on ultrasound of the abdomen, upper gastrointestinal endoscopy and colonoscopy. Based on the above findings, a diagnosis of Laugier-Hunziker syndrome was made and the benign nature of the disease was explained to the patient.

Laugier and Hunziker first described this disease as an acquired, benign skin condition characterized by buccal mucosal pigmentation with longitudinal melanonychia [2]. The condition is also referred to as idiopathic lenticular mucocutaneous pigmentation [3]. The disease has a mean age of onset at 50 years. The etiology is not clear. One case of familial LHS in a mother and two daughters has been reported [4]. The pigmentation occurs after an unknown trigger that leads to increased formation of melanosomes and their transport to the basal cells [5].

The disease arises as dark brown smooth linear or lenticular macules on the lips and oral mucosa, gums, tongue, sclera, esophagus, perineum and fingers [6]. More than half of patients have involvement of nails in the form of longitudinal, partial or complete melanonychia [5]. Pseudo-Hutchinson sign is said to be present when melanonychia is accompanied by pigmentation of the proximal nail fold [7]. Involvement of the genital mucosa is rare, and penile involvement has only been rarely reported $[8,9]$. Histopathology shows a normal number of melanocytes but an increased number of melanophages in the dermis and basal cell pigmentation.
The diagnosis is usually one of exclusion. The differential diagnosis includes Peutz-Jeghers syndrome, an autosomal dominant disease, associated with intestinal polyposis that spares the nails. Cronkhite Canada syndrome (CCS) presents with alopecia, nail dystrophy and intestinal polyposis in addition to mucocutaneous pigmentation. Bandler syndrome has intestinal vascular malformations apart from pigmentation of skin and nails. Albright syndrome is characterized by unilateral pigmentation, precocious puberty and fibrous dysplasia. Addison's disease presents with pigmentation of sun-exposed skin, scars, mucosa, palmar creases and weakness, hypertension and weight loss. Drugs such as tetracyclines, antimalarials, chemotherapeutic agents, amiodarone, zidovudine and heavy metals such as silver, gold and mercury may produce mucocutaneous pigmentation [10].

Treatment for pigmentation can be done by Q-switched Nd:YAG or Q-switched Alexandrite laser. Sun protection should be advised [10].

Laugier-Hunziker syndrome is a rare disease with only a few case reports from India. Genital pigmentation is rare in LHS. Our case is probably the first report of penile pigmentation in a patient with LHS from India. Thus our case is rare and hence we have reported it.

\section{References}

1. Sachdeva S., Sachdeva S., Kapoor P.: Laugier Hunziker syndrome: a rare cause of oral and acral pigmentation. J Cutan Aesthet Surg 2011, 4, 58-60. 
2. Laugier P., Hunziker N.: Essential lenticular melanic pigmentation of the lip and cheek mucosa. Arch Belg Dermatol Syphiligr 1970, 26, 391-399.

3. Lalosevic J., Zivanovic D., Skiljevic D., Medenica L.: Laugier Hunziker syndrome - case report. An Bras Dermatol 2015, 90 (3 suppl 1), 223-225.

4. Makhoul E.N., Ayoub N.M., Helou J.F., Abadjian G.A.: Familial Laugier-Hunziker syndrome. J Am Acad Dermatol 2003, 49, S143-S145.

5. Nayak R.S., Kotrashetti V.S., Hosmani J.V.: Laugier Hunziker syndrome. J Oral Maxillofac Pathol 2012, 16, 245-250.

6. Barman P.D., Das A., Mondal A.K., Kumar P.: Laugier-Hunziker syndrome revisited. Indian J Dermatol 2016, 61, 338-339.

7. Porneuf M., Dandurand M.: Pseudomelanoma revealing Laugier Hunziker syndrome. Int J Dermatol 1997, 36, 138-141.

Submitted: 10 VII 2016

Accepted: 15 IX 2016
8. Ayoub N., Barete S., Bouaziz J.D., Le Pelletier F., Frances C.: Additional conjunctival and penile pigmentation in Laugier-Hunziker syndrome: a report of two cases. Int J Dermatol 2004, 43, 571-574.

9. Mignogna M.D., Lo Muzio L., Ruoppo E., Errico M., Amato M., Satriano R.A.: Oral manifestations of idiopathic lenticular mucocutaneous pigmentation (Laugier Hunziker syndrome): a clinical, histopathological and ultrastructural review of 12 cases. Oral Dis 1999, 5, 80-86.

10. Rangwala S., Doherty C.B., Katta R.: Laugier Hunziker syndrome: a case report and review of the literature. Dermatol Online J 2010, 16, 9 .

Mohammad Adil, Tasleem Arif, Syed Suhail, Manu Singh

Jawaharlal Nehru Medical College, Aligarth Muslim University, Aligarth, India 